\title{
TYÖSSÄOPPIMISEN \\ TEOREETTISIA LÄHTÖKOHTIA
}

\author{
Katsaus erilaisiin transfer-käsityksiin
}

Terttu Tuomi-Gröhn

\begin{abstract}
Transferissa on kysymys siitä, miten hyvin yksilö pystyy
hyödyntämään yhdessä tehtävässä tai tilanteessa

oppimaansa tietoa tai osaamista uudessa tilanteessa.

Tässä artikkelissa käsitettä on kehitelty pidemmälle, tarjoamaan välineitä muuttuvien tietojen ongelmaan ja muuttuvien tilanteiden kohtaamiseen.
\end{abstract}

$\mathrm{T}$ yössäoppiminen ja työelämäyhteydet ovat nousseet ammatillisessa koulutuksessa keskeiselle sijalle (Koulutuksen ja korkeakouluissa harjoitettavan tutkimuksen kehittämissuunnitelma 1995-2000, Työelämäosaamisen tehostamisohjelma 1998-2000, Opetushallitus). Opetusviranomaiset ovat korostaneet, että nykyinen työssäoppiminen poikkeaa entisestä työharjoittelusta: nyt on kysymys oikeiden tehtävien yhteydessä tapahtuvasta ohjatusta oppimisesta. Voidaan kuitenkin kysyä, miksi työssäoppiminen ja työelämäyhteydet ovat saaneet näin korostuneen aseman.

Eräs syy tähän on se, että koulussa opitun ja työtoiminnan välinen suhde ei ole kitkaton. Monet tutkimukset ovat osoittaneet (mm. Gruber et al. 1996, Mayer \& Wittrock 1996), että osaaminen ja tieto ei välttämättä siirry tehtävästä toiseen. Oppilaitokseen ja työpaikalle syntyy helposti kaksi erillistä tietovarastoa, kun koulutuksessa omaksuttuja tietoja ja taitoja ei osata hyödyntää käytännön työtehtävien ratkaisemisessa. Ne ratkaistaan työkokemukseen perustuvan tiedon varassa. Toisaalta työelämä muuttuu nopeasti ja koulujen on vaikea pysyä tässä muutoksessa mukana. Koulun vaarana on opettaa eilisen tietoja ja työkäytäntöjä. Yhtenä ratkaisuna näihin ongelmiin on työssä tapahtuvaa oppimista lisätty sekä esitetty vaatimuksia koulun ja työelämän välisen vuorovaikutuksen tehostamisesta. Miten työssäoppimista tulisi kehittää, että kahden erillisen osaamisjärjestelmän ongelmasta päästäisiin ja koulu pysyisi työelämän muutoksissa kiinteästi mukana?

$\mathrm{O}$ ppimisteoreettisesti tarkastellen yhden näkökulman tähän monimutkaiseen kysymykseen tarjoaa siirtovaikutuksen eli transferin käsite. Transfer-kysymykset ovat olleet viime aikoina kiinnostuksen kohteena sekä kansainvälisesti (esimerkiksi Beach 1999) että kansallisesti (Soini 1999). Traditionaalisesti määriteltynä transferissa on kysymys siitä, miten hyvin yksilö pystyy hyödyntämään yhdessä tehtävässä tai tilanteessa oppimaansa tietoa tai osaamista uudessa tilanteessa (esim. Mayer \& Wittrock 1996). Tämä artikkeli perustuu Helsingin yliopiston toiminnan teorian ja kehittävän työntutkimuksen yksikössä toimivaan projektiin (Tuomi-Gröhn et al. 
2000), jonka teoreettisena lähtökohtana on ekspansiivinen oppiminen ja kehittävä transfer. Sen mukaan työssäoppiminen ei tarkoita vain yksilön oppimista, vaan koulun ja työpaikan yhteistyöhön perustuvaa yhteistoiminnallista tiedon tuottamista työpaikan ongelmien ratkaisemiseksi. Kehittävän transferin käsite tarjoaa välineen muuttuvien tietojen ongelmaan ja muuttuvien tilanteiden kohtaamiseen, seikat jotkat klassisissa transfer-käsityksissä ovat jääneet vähälle huomiolle. Sen lisäksi perustana on ajatus, että myös työpaikan tulisi hyötyä opiskelijoiden työharjoittelusta eikä olla vain antavana ja ohjaavana osapuolena. Klassiset transfer-käsitykset tarkastelevat työssäoppimista vain koulun ja opiskelijan näkökulmasta. Tämän artikkelin tavoitteena on erilaisten transfer-käsitysten analyysi. Sitä kautta pyritään luomaan pohjaa erilaisten työssäoppimisen käytäntöjen, ja erityisesti kehittävään transferiin perustuvan yhteistoiminnallisen työssäoppimisen ymmärtämiselle.

Erilaiset transfer-käsitykset voidaan jakaa karkeasti kolmeen ryhmään. Transferin perustana on 1) joko tiedon siirto tehtävästä toiseen,

2) yksilöllinen taipumus tuottaa koulussa opittuja ajattelutapoja koulun ulkopuolella taikka

3) toiminnan jatkuvuus tilanteesta toiseen interaktiossa sosiaalisen kontekstin kanssa.

Seuraavassa nämä erilaiset käsitykset ja niihin liittyvät työssäoppimisen käytännöt esitellään tarkemmin (erilaisista transfer-käsityksistä laajemmin ks. Tuomi-Gröhn \& Engeström, a).

\section{Tiedon siirto tehtävästä toiseen koulutilanteessa}

$\mathrm{T}$ horndike ja identtiset elementit. Thorndiken (1924) mukaan oppimisen siirtovaikutusta tapahtuu vain silloin, kun jonkin aineen spesifiä sisältöä tarvitaan toisen aineen oppimiseen tai tehtävän suorittamiseen. Transfer perustuu "identtisiin elementteihin" ja on siten hyvin spesifiä luonteeltaan. Identtisten elementtien soveltaminen opetukseen merkitsi oppiaineksen jakamista pieniin osiin ja opettamista toistoon perustuen siten, että alemman tason taidot hal- littiin ennen korkeamman tasoisia taitoja. On helppoa nähdä tämän ajattelun jatkuvuus magerilaisessa käyttäytymistavoitteiden asettamisessa. Se näkyi myös ammattianalyyseinä, ammatillisten työtaitojen tutkimisena, tarkoituksena opettaa työssä tarvittavia taitoja sellaisenaan koulutuksessa.

J udd ja yleiset periaatteet. Judd (1939) kritisoi että tiedon siirtymisen perustana eivät ole sisällöllisesti samanlaiset elementit, vaan yleiset strategiat tai periaatteet, joilla kaksi sisällöltään erilaista tehtävää voidaan ratkaista. Juddin mukaan siirtovaikutusta tapahtuu eniten silloin, kun opetetaan yleisiä periaatteita niitä tietoisesti reflektoiden. Juddin ajattelumallin jatkaja löytyy myöhemmin Jerome Brunerista (1969) joka korostaa oppiaineiden syvärakenteita ja yleisiä periaatteita transferin lähtökohtana. Tämä opetusajattelu näkyy tänäkin päivänä ilmiöpohjaisen oppimisen korostamisena.

\section{ognitiiviset ja konstruktivistiset näkemykset. Kognitiivisen psykologian edustajat hahmot-} tavat erilaisia transfer-tyyppejä. Näitä ovat lähitransfer tietojen siirtona identtisiin ja kaukainen transfer erilaisiin tilanteisiin. Samoin erotetaan spesifi ja yleinen transfer (Gick \& Holyoak 1993), pintarakenteiden ja syvärakenteiden transfer (Detterman 1993) ja vielä aktiivinen transfer (high road) ja passiivinen transfer (low road) (Perkins ja Salomon 1987). Kaikissa näissä on kuitenkin takana skeeman käsite, johon tiedon siirtyminen tehtävästä tai tilanteesta toiseen perustuu. Myös metakognition rooli korostuu (Gick \& Holyoak 1987). Oppijan aktiivinen 
tehtävä on tunnistaa uudessa tilanteessa tai tehtävässä aiemmasta tehtävästä tuttu skeema. Opetukseen sovellettuna kognitiivinen käsitys merkitsee tarkkojen rakenteellisten skeemojen tai ennakkojäsentäjien käyttöä uuden informaation organisoinnin apuna. Suomessa äskettäin ilmestynyt Tiina Soinin (1999) väitöskirja edustaa konstruktivistista näkemystä. Hän kutsuu tähän näkemykseen perustuvaa siirtovaikutusta aktiiviseksi transferiksi. Se perustuu (Soini 1999, 70) oppijan intentionaaliseen toimintaan sekä oppimisprosessin että transfer-tehtävän aikana. Aktiivinen transfer edellyttää metakognitiivisten taitojen tietoista käyttöä, jotta opittu tieto olisi käytettävissä uudessa kontekstissa. Kuitenkaan useimmat kognitiiviseen näkemykseen perustuvat tutkimukset eivät sisällä intentionaalista oppimista transfer-tehtävässä. Siirtovaikutus perustuu ensin opitun tehtävän heijastumiseen transfer-tehtävän suorittamiseen.

$\mathrm{E}$ dellä kuvatuille transfer-käsityksille on tyyillistä, että niillä kuvataan kouluoppimisen ongelmia, tiedon siirtymistä tehtävästä toiseen. Niissä ei tarkastella koulun ulkopuolisessa maailmassa tapahtuvaa toimintaa eikä koulussa tai työpaikoilla tapahtuvia muutoksia. Sen vuoksi ne eivät ole omiaan antamaan välineitä koulun ja työpaikkojen väliseen tietojen ja toiminnan liikkuvuuteen.

\section{Yksilöllinen luonteenlaatu ja opitun siirtyminen koulun ulkopuolelle}

aajassa kognitiivisten transfer-käsitysten jou-
kossa on yksi, joka ansaitsee työssäoppimisen kannalta erillisen tarkastelun. Bereiter (1995) erottaa kahdenlaisen transferin olemassaolon. Ensimmäinen, periaatteiden siirtovaikutus, tarkoittaa sitä, että opiskelijat tunnistavat koulun ulkopuolisissa tilanteissa, mitä opittuja periaatteita voitaisiin soveltaa. Toisenlainen transfer, luonteen laatuun perustuva (dispositions) siirtovaikutus, kuvaa sitä, onko yksilö halukas ja kykenevä soveltamaan opittuja periaatteita arkitodellisuudessa. Erottelun tekee ymmärrettäväksi Bereiterin tapa pitää mentaalisia kykyjä, kuten kriit- tistä ajattelua, luonteen taipumuksena rehellisyyden tai ystävällisyyden tapaan. Esimerkkinä Bereiter maintsee moraalikasvatuksen. Vaikka ihmiselämän kunnioittamisen periaatteet olisi opittu kuinka hyvin tahansa, ei niiden mukaan välttämättä toimita kriisitilanteissa. Luokassa opittu häviää helposti luokan ulkopuolella, ja tämä on varsinainen transferin ongelma. Tämän näkemyksen mukaan transferin perusta ei olekaan ensisijaisesti opetettavassa aineessa, vaan yksilössä ja hänen luonteen laadussaan.

Miten koulut sitten voivat edistää tällaista transferia? Bereiter (1995, 29-30) puhuu tilanteiden (situations) transferista eikä niinkään tilanteiden yli tapahtuvasta transferista. Koulussa toteutuva ajattelutapa, esimerkiksi kriittinen reflektointi, voi ohjata opiskelijan hakemaan ja luomaan samanlaista ajattelutapaa tuottavia tilanteita koulun ulkopuolella.

Bereiterin näkemys on ansiokas siinä mielessä, että se kiinnittää huomion koulun ulkopuolisiin tilanteisiin ja korostaa tilanteiden luomista, ei "oikean" vastauksen antamista annettuun ongelmaan. Työssäoppimisen kannalta on mielekästä ajatella, että opiskelija, joka on oppinut koulutuksessa tiettyjä periaatteita, pyrkii luomaan työpaikalle tilanteita, joissa samat periaatteet toteutuvat. Yliopistojen tieteellinen koulutus perustuu tähän. Opiskelijoille opetetaan kriittistä tieteellistä ajattelua ja oletetaan, että se siirtyy työelämään. Myös muilla koulutuksen tasoilla voidaan ajatella Bereiterin näkemyksen toteutuvan. Esimerkkinä mainittakoon hoitoalalta potilaan kohtaaminen tasavertaisena oman asiansa subjektina taikka kaupan alalla rehellisyyden ja luotettavuuden periaatteena asiakkaan kohtelussa. Jos opiskelija on kohdannut näitä periaatteita ja niihin liittyvää keskustelua koulutuksensa aikana, hän pyrkii tuottamaan sellaisia myös myöhemmissä työkäytännöissä. Kuitenkin Bereiter pitää taipumuksia yksilöllisinä ja jättää huomiotta taipumusten kulttuurisen ja sosiaalisen luonteen (ks. D’Andrade ja Strauss 1992). Hän ei kiinnitä huomiota työyhteisön kulttuuriin ja sosiaaliseen yhteistoimintaan, joka on kuitenkin hyvin merkityksellinen työssäoppimisen kannalta. 


\section{Kontekstin ja sosiaalisen vuorovaikutuksen merkitys}

$\mathrm{T}$ ilannesidonnaiset (situated) näkemykset. Lave (1988) kritisoi kognitiivisesti orientoituneita transfer-näkemyksiä siitä, että yksilöllinen kognitio on erotettu sosiaalisesta maailmasta. Laven mukaan tieto on niin suuressa määrin tilanteeseen sitoutunutta, että sitä ei voida siirtää, vaan se on tuotettava jokaisessa tilanteessa erikseen. Greeno et al. (Greeno, Moore \& Smith 1993) ottavat maltillisemman kannan ja väittävät, että kognitivistien korostamat abstraktit skeemat voivat olla transferin kannalta merkityksellisiä, mutta epätyypillisiä. Heidän mukaansa transfer perustuu tavallisemmin toiminnan jatkuvuuteen eri tilanteissa. Jatkuvuutta voidaan kuvata toimintaskeemoilla, viitaten toimintaa ohjaavaan periaatteeseen eikä niinkään abstraktiin kognitiiviseen skeemaan. Opetuksen tulisi pyrkiä siihen, että huomio kiinnitetään jatkuvuutta luoviin toimintaskeemoihin, jotka sisältävät materiaalisia ja sosiaalisia tekijöitä kognitiivisten lisäksi. Oppimisympäristön tulisi sisältää yhteistoiminnallisia tilanteita, joissa opettajat toimivat kumppaneina, valmentajina ja malleina ja joissa opiskelijat osallistuvat ongelman ratkaisuun.

Greenon näkemys on yksi muunnelma oppipoikamalleista, jotka kuvaavat noviisien siirtymistä asiantuntijoiksi (Lave \& Wenger 1991, vrt. myös Vygotsky 1978). Tilannesidonnaisessa näkemyksessä tiedon omaksumisen sijaan oppimisen keskeiseksi tekijäksi nousee osallistuminen tuottavaan toimintaan. Noviisi-asiantuntijamalli on traditionaalisesti ollut työssä oppimisen taustalla. Koulutuksen työelämäjaksojen tarkoituksena on, että opiskelija omaksuu kokeneempien työntekijöiden toimintatapoja ja kehittyy vähitellen itsekin.

Ongelmana on kuitenkin se, että ekspertin tai opettajan oletetaan omaavan sen tiedon, jolla ongelmat voidaan ratkaista. Malli ei ota huomioon sitä, että työpaikat ovat nykyään jatkuvassa muutoksen tilassa eikä välttämättä ole ketään asiantuntijaa, joka tietäisi ratkaisut ongelmiin.
O osiokulttuuriset näkemykset. Beach (1999) Niinnittää huomion tilanteiden muuttumiseen. Transfer merkitsee siirtymää kahden muuttuvan tilanteen välillä eikä vain tiedon tai taidon siirtoa muuttumattomasta tilanteesta toiseen. Transfer-tilanne saattaa merkitä kokonaan uudenlaisten toimintojen tuottamista. Beach on ehdottanut transferin käsitteellistämistä uudella tavalla, siten että yksilöiden toimintaa tarkastellaan seuraamuksellisina siirtyminä (consequential transition) erilaisten muuttuvien sosiaalisten organisaatioiden välillä tai muuttuvan organisaation sisällä. Kysymys on uuden toiminnan luomisesta jatkuvassa ympäristön kanssa yhteistyössä tapahtuvassa prosessissa. Työssäoppimisessa ei ole silloin kysymys tiedon siirrosta koulusta työhön tai kokeneemman työntekijän työtapojen omaksumisesta, vaan uuden toiminnan luomisesta yhdessä muiden kanssa aikaisempiin tietoihin ja taitoihin perustuen. Siirtymän suunta ei ole vain koululta työpaikalle, vaan myös työpaikalta kouluun tai kotoa kouluun. Kaikki siirtymät sisältävät niin tietojen ja taitojen kuin identiteetinkin rakentumista eikä niinkään yhdessä tilanteessa opitun soveltamista toiseen tilanteeseen.

Tämän tyyppinen transfer-käsitys työssäoppimisen perustana ottaa huomioon muuttuvat tilanteet ja useamman organisaation, jolloin transfer määritetään liikkumisena organisaatioiden rajojen yli. Työssäoppimisen perusta on koulun ja työpaikan välisessä liikkumisessa ja tiedonkulku on molemminpuolista. Kysymys ei ole pelkästään olemassa olevien tietojen siirtymisestä, vaan tietojen ja taitojen tuottamisesta uudessa muuttuvassa tilanteessa tai ympäristössä. Työssäoppimisen tavoitteena on tämän näkemyksen mukaan yksilön koko identiteetin ja toiminnan vähittäinen muuttuminen vuorovaikutuksessa muuttuvan työpaikan ja koulun toimintaympäristöjen kanssa. Beachin muutoin niin innovatiivisen näkemyksen rajoituksena on kuitenkin se, että siinä ei kiinnitetä huomiota niihin välineisiin, joilla siirtymiä ja muutoksia voitaisiin tuottaa.

$\mathrm{T}$ oiminnanteoreettiset näkemykset. Kulttuuri-historialliseen toiminnan teoriaan pohjaava Da- 
vydov (1990) kritisoi yleisesti vallitsevaa koulukäytäntöä, jonka kohteena ei ole oppiminen, vaan koulunkäynti sinänsä. Hän kehitti käsitteen oppimistoiminta uutena oppimisen tyyppinä, jonka tavoitteena on saada oppiminen koulunkäynnin kohteeksi muodostamalla tiettyihin oppimistekoihin perustuva sisällöllinen, teoreettinen suhde todellisuuteen. Davidovin työ kärsii kuitenkin siitä, että sen sovellukset perustuivat yksilölliseen oppimiseen ja rajoittuivat kouluun ja luokkaympäristöön. Davidov ei koskaan tutkinut työn ja koulun välisiä siirtymiä. Täten Davydovin ajatukset eivät sellaisenaan anna evästystä työssäoppimisen problematiikkaan. Toiminnan teorian ja kehittävän työntutkimuksen piirissa (Engeström 1987, 1991) on kuitenkin jatkettu transferin ja samalla työssäoppimisen teoreettisten perusteiden kehittelyä pohjaamalla Davydovin ajatuksiin, mutta laajentamalla oppimisen analyysiyksikkö yhteistoiminnalliseksi ja myös työpaikan huomioon ottavaksi. Keskeinen käsite on ekspansiivinen oppiminen, jonka mukaan toimintajärjestelmä ja yksilöllinen oppiminen kietoutuvat toisiinsa ja yksilöllinen oppiminen on mahdollista ymmärtää vain koko organisaation osana.

Kulttuuri-historiallinen toiminnan teoria määrittää oppimisen analyysiyksiköksi historiallisesti kehittyvän, kollektiivisen ja artefaktien välittämän toimintajärjestelmän (Leontjev 1978). Koulu tai työpaikka ovat esimerkkejä toimintajärjestelmistä. Ekspansiivinen oppiminen alkaa, kun joku organisaation yksilö kyseenalaistaa olemassa olevan käytännön. Tämä voi johtaa laajenevaan debattiin ja nykytilan ristiriitojen yhteistoiminnalliseen analyysiin, joka taas saattaa johtaa toiminnan uuden, kehittyneemmän muodon mallittamiseen, jossa ristiriidat on ratkaistu. Malli ja sen seuraukset tutkitaan ja pannaan käytäntöön askel askeleelta. Tämä johtaa uuden toimintamuodon lujittumiseen, leviämiseen ja prosessin reflektiiviseen arviointiin.

Ekspansiivisen oppimisen mallissa pyritään siis muutoksen tuottamiseen toimintajärjestelmässä: työpaikassa tai oppilaitoksessa, sen vuoksi siihen perustuvaa transferia kutsutaan kehittäväksi transferiksi. Se antaa myös välineet muutoksen tuottamiseen eli edellä kuvatun prosessin nykykäytännön kyseenalaistamisesta uuden toiminnan mallittamiseen, käyttöön ottoon ja arviointiin. Koulutusinstituutioiden kannalta tarkasteltuna koulusta tulee kollektiivinen muutosagentti, joka tekee yhteistyötä paikallisten organisaatioiden ja työpaikkojen kanssa tavoitteena löytää ja tuottaa kehittyneempiä työkäytäntöjä. Käytännössä tämäntyyppinen kehittävä transfer syntyy siten, että koulu tarjoaa asiantuntemuksensa muutoksessa oleville työpaikoille. Se tapahtuu opiskelijoiden työssäoppimisen jaksojen yhteydessä pienen kehittämisprojektin muodossa, josta on vastuussa opiskelijan, opettajan ja työpaikkaohjaajan muodostama yhteistoiminnallinen tiimi. Koulun teoreettinen tieto kohtaa työpaikkojen arkikokemukset ja parhaimmillaan syntyy uuttaa luovaa, hedelmällistä vuorovaikutusta näiden välille. Transferin kannalta on oleellista, että tiedon lisäksi siirtyy työtapa, jolla voidaan ratkaista sellaisia ongelmia, joihin valmiita vastauksia ei ole olemassa. Tällä tavoin pystytään kohtaamaan uusia, muuttuvia tilanteita. Tässä on kehittävän trasferin ja siihen perustuvan työssäoppimisen ydin. Ekspansiivisen oppimisen ja kehittävän transferin projekteissa kaikki kolme osapuolta oppivat ja hyötyvät: koulu, opiskelija ja työpaikka. Silloin työssäoppiminen ei tarkoita pelkästään muuttumattomien työkäytäntöjen omaksumista, vaan aktiivista yhteistoiminnallista uusien tietojen ja työkäytäntöjen tuottamista. Tämä laajentaa radikaalisti työssäoppimisen näkymiä.

\section{Transfer-käsitysten ja niihin liittyvän työssäoppimisen vertailua}

Erilaiset transfer-käsitykset ja niiden konseptiot työssäoppimisesta on vielä koottu seuraavaan taulukkoon.

Tässä tarkastellut transfer-käsitykset ovat syntyneet erilaisissa konteksteissa erilaisia tarpeita varten. Ylimmässä lokerossa olevat mallit ovat syntyneet pohdittaessa kouluoppimisen ongelmia sekä ns. akateemisten tietojen ja taitojen käyttöä koulun ulkopuolisissa tilanteissa. Tilannesidon- 


\begin{tabular}{|c|c|c|}
\hline Suuntaus & Transferin perusta & Työssäoppimisen muoto \\
\hline & Tehtävä & \\
\hline Thorndike & Identtiset elementit & Tuttujen sisältöjen löytäminen \\
\hline Judd & Yleiset periaatteet & $\begin{array}{l}\text { Tuttujen periaatteiden soveltami- } \\
\text { nen }\end{array}$ \\
\hline \multicolumn{2}{|c|}{$\begin{array}{l}\text { Kognitiiviset näkemyksetSkeemat, metakognitio } \\
\text { (esim. Gick \& Holyoak) }\end{array}$} & $\begin{array}{l}\text { Tuttujen tiedollisten skeemojen } \\
\text { tunnistaminen }\end{array}$ \\
\hline \multirow[t]{2}{*}{ Bereiter } & Yksilö & $\begin{array}{l}\text { Koulussa opitun diskurssin tuotta- } \\
\text { minen tai niihin hakeutuminen } \\
\text { koulun ulkopuolella }\end{array}$ \\
\hline & Konteksti & \\
\hline $\begin{array}{l}\text { Tilannesidonnaiset } \\
\text { näkemykset (esim. } \\
\text { Lave ja Greeno) }\end{array}$ & $\begin{array}{l}\text { Sosiaalinen osallistuminen } \\
\text { yhdessä organisaatiossa }\end{array}$ & $\begin{array}{l}\text { Oppijan työkäytäntöjen muutta- } \\
\text { minen kokeneemman opastuksella }\end{array}$ \\
\hline $\begin{array}{l}\text { Sosio-kulttuuriset } \\
\text { näkemykset (Beach) }\end{array}$ & $\begin{array}{l}\text { Yksilölliset siirtymät } \\
\text { organisaatiosta toiseen }\end{array}$ & $\begin{array}{l}\text { Oppijan identiteetin, tietojen ja } \\
\text { työkäytäntöjen muuttuminen } \\
\text { muuttuvissa organisaatioissa }\end{array}$ \\
\hline $\begin{array}{l}\text { Toiminnanteoreettiset } \\
\text { näkemykset (Davidov, } \\
\text { Engeström) }\end{array}$ & $\begin{array}{l}\text { Yhteistoiminnallinen kehittä- } \\
\text { vä toiminta kahden toiminta- } \\
\text { järjestelmän rajapinnalla }\end{array}$ & $\begin{array}{l}\text { Työyhteisön tietojen ja työkäytän- } \\
\text { töjen muuttaminen muuttuvissa } \\
\text { organisaatioissa }\end{array}$ \\
\hline
\end{tabular}

naiset näkemykset ovat syntyneet yhteisöissä tapahtuvia arkielämän käytäntöjä tutkittaessa. Tällöin keskeistä on ollut oppijan identiteteetti ja sen rakentuminen näissä yhteisöissä. Sosiokulttuuriset ja toiminnan teoreettiset käsitykset ovat kehittyneet pyrittäessä ymmärtämään työssä ja konkreettisessa toiminnassa tapahtuvaa oppimista ja tällaisen oppimisen konteksteja. Näin kullakin käsityksellä on oma teoriahistoriallinen lähtökohtansa ja näkökulmansa transfer-keskusteluun. Koska työssäoppiminen on noussut keskeiseksi koulutuksen haasteeksi, on tässä artikkelissa tarkasteltu myös traditionaalisen koulukeskeisen lähtökohdan ylittäviä transfer-käsityksiä, koska niillä saattaa olla annettavaa työssäoppimisen kannalta myös koulukontekstissa.

Tehtäviin perustuvalla transferilla on keskeinen asema nykyisessä koulujärjestelmässä. Peruskoulun opetussuunnitelma perustuu konstruktivistiseen oppimiskäsitykseen ja sitä vastaavaan ak- tiivisen transferin käsitteeseen. Oppijoiden tehtävänä on löytää yhteisiä rakenteita, skeemoja erilaisista ilmiöistä ja hyödyntää niitä ongelmien ratkaisussa. Ammatillisessa koulutuksessa puhutaan ilmiöpohjaisesta oppimisesta. Sillä on yhteyksiä tähän näkemykseen.

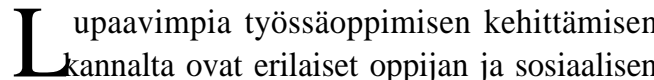
kontekstin vuorovaikutukseen perustuvat ajattelutavat. Traditionaalisesti sitä edustaa oppipoika-asiantuntijamalli, jossa työtaitoja opitaan yhteistyössä kokeneempien kanssa. Simuloidut oppimisympäristöt pyrkivät myös lisäämään teoreettisen tiedon ja työelämän välistä yhteyttä. Niiden etuna on pyrkimys tuottaa uutta tietoa ongelmien ratkaisuun usein monimutkaisissakin oppimisympäristöissä. Ongelmana on se, että simuloituja ympäristöjä on vaikea pitää työelämän muutosten tasalla. Myös oppimisen motivaatio on koulukeskeinen, kun opiskelija ei ole aidos- 
ti vastuussa työn tuotannollisesta tuloksesta. Toisaalta tämä luo myös turvallisuutta, ei pystytä aiheuttamaan haittoja oikeille asiakkaille. Simuloidut tilanteet eivät myöskään tue opiskelijan koko identiteetin, tietojen ja toiminnan muotoutumista koulun ja työpaikan välillä liikuttaessa. Tosin viime aikoina on kehitelty aidon ja simuloidun oppimisympäristön yhdistäviä opetusmuotoja (ks. esim. Fuerstenau), joissa tämä ongelma vähenee. Parhaiten myös työpaikkaa hyödyntävän työmuodon tarjoaa kehittävä transfer ${ }^{1}$, jonka tavoitteena on kehittää työpaikan toimintoja ja tuottaa opiskelijoille, työpaikan edustajille ja opettajalle välineitä uuden, tuntemattoman kohtaamiseen yhteistoiminnallisessa prosessissa. Transferin perustana on yhteistoiminnallisen, kehittävän työtavan siirtyminen tilanteesta toiseen niin työpaikalla kuin oppilaitoksessakin.

\section{Viite}

Kehittävästä transferista on tekeillä kaksi kirjaa. Tuomi-Gröhn, T. \& Engeström, Y. (Eds.), New perspectives on transfer and boundary crossing ja Tuomi-Gröhn, T. \& Engeström, Y. (toim.) Koulun ja työn rajavyöhykkeellä. Molempien kirjojen on tarkoitus valmistua vuoden 2001 aikana.

\section{Lähteet}

BEACH, K. 1999. Consequential transitions: A sociocultural expedition beyound transfer in education. Review of Research in Education, 28, 46-69.

BEREITER, C. 1995. A Dispositional view of transfer. Teoksessa A. McKeough, J. Lupart \& A. Marini (toim.), Teaching for transfer: Fostering generalization in learning. Hillsdale: Lawrence Erlbaum.

BRUNER, J. 1969. The process of education. Cambridge: Harvard University Press.

D'ANDRADE, R. G. \& Strauss, C. (toim.), 1992. Human motives and cultural models. Cambridge: Cambridge University Press.

DAVYDOV, V. V. 1990. Types of generalization in instruction. Reston: National Council of Teachers of Mathematics.

DETTERMAN, D. K. 1993. The case for the prosecution: Transfer as an epiphenomenon. Teoksessa D.K. Detterman \& R.J. Sternberg (toim.) Transfer on trial: Intelligence, cognition and instruction. Norwood: Ablex.

ENGESTRÖM, Y. 1987. Learning by expanding: An activity-theoretical approach to developmental research. Helsinki: Orienta-Konsultit.

ENGESTRÖM, Y. 1991. Developmental work research: Reconstructing expertise through expansive learning. Teoksessa M. I. Nurminen \& G. R. S. Weir (toim.), Human jobs and computer interfaces.
Amsterdam: Elsevier.

FUERSTENAU, B. Exploration of an industrial enterprise as a method of boundary crossing in vocational education. Teoksessa T. Tuomi-Gröhn \& Y. Engeström (toim.) New perspectives on transfer and boundary crossing. (Käsikirjoitus)

GICK, M. L. \& Holyoak, K. L. 1987. The cognitive basis of knowledge transfer. Teoksessa S. M. Cormier \& J. D. Hagman (toim.), Transfer of learning. New York: Academic Press.

GICK, M.L. \& Holyoak, K.J. 1993. Schema induction and analogical transfer. Cognitive Psychology, 15, $1-38$.

GREENO, J. G., Smith, D. R. \& Moore, J. L. 1993. Transfer of situated learning. Teoksessa D. K. Detterman \& R. J. Sternberg (toim.), Transfer on trial: Intelligence, cognition and instruction. Norwood: Ablex.

GRUBER, H., Law, L., Mandl, H. \& Renkl, A. 1996. Situated learning and transfer. Teoksessa P. Reimann \& H. Spada (toim.), Learning in humans and machines: Towards an interdisciplinary learning science. Oxford: Pergamon Press.

JUDD, C. H. 1939. Educational psychology. New York: Houghton Mifflin.

LAVE, J. 1988. Cognition in practice: Mind, mathematics and culture in everyday life. Cambridge: Cambridge University Press.

LAVE, J. \& Wenger, E. 1991. Situated learning: Legitimate peripheral participation. Cambridge: Cambridge University Press.

LEONT'EV, A. N. 1978. Activity, consciousness, and personality. Englewood Cliffs: Prentice-Hall.

MAYER, R.E. \& Wittrock, M.C. 1996. Problem-solving transfer. Teoksessa D. C. Berliner \& R. C. Calfee (toim.), Handbook of educational psychology. New York: Simon \& Schuster.

PERKINS, D.N. \& Salomon, G. 1987. Transfer and teaching thinking. Teoksessa D.N. Perkins, J. Lochhead \& J. Bishop (toim.) Thinking: The second international conference. Hillsdale: Lawrence Erlbaum.

THORNDIKE, E. L. 1924. Mental discipline in high school studies. Journal of Educational Psychology, 15, 1-22, 83-98.

TUOMI-GRÖHN, T. \& Engeström, Y. a) Conceptualizing transfer: from standard notions to developmental perspectives. Teoksessa T. Tuomi-Gröhn \& Y. Engeström (toim.), New perspectives on transfer and boundary crossing (käsikirjoitus)

TUOMI-GRÖHN, T. \& Engeström, Y. (toim.) b) Koulun ja työn rajavyöhykkeellä. (käsikirjoitus)

TUOMI-GRÖHN, T., Engeström, Y., Hukka, K., Härkäpää, L. Konkola, R., Lambert, P. Lukkarinen, T. ja Ranta-aho, S. 2000. Työssäoppiminen ja kehittävä siirtovaikutus. Ammattikasvatuksen aikakauskirja 1, 45-54.

VYGOTSKY, L.S. 1987. Mind in society. The development of higher psychological processes. London: Harvard University Press.

Artikkeli saapui toimitukseen 29.5.2000. Se hyväksyttiin julkaistavaksi toimituskunnan kokouksessa 23.10.2000. 